\title{
Performance Evaluation and Off Design Analysis of the HP and LP Feed Water Heaters on a $3 \times 135$ MW Coal Fired Power Plant
}

\author{
Jameson R Almedilla ${ }^{*}$, Leonel L Pabilona ${ }^{1}$ and Eliseo P Villanueva ${ }^{2}$
}

${ }^{1}$ Department of Mechanical Engineering, University of Science and Technology of Southern Philippines, CM Recto Avenue, Lapasan, Cagayan De Oro City, Philippines ${ }^{2}$ Department of Mechanical Engineering, Mindanao State University-Iligan Institute of Technology, Tibanga, Iligan City, Philippines

\begin{abstract}
System composing of two high pressure heaters (HPH1 and HPH2), one deaerator-feed water tank (DEA) and four low pressure heaters (LPH4, LPH5, LPH6 and LPH7). This study aims to conduct a performance evaluation during full load on each unit's regenerative feed water heaters, both closed and open type, using ASME PTC 12.1 and an analysis on the heater off design condition at $5 \%$ load intervals. Off design conditions on a heater occurred on several occasions, where unit is at low load or derating, and may affect overall efficiency of a plant. The parameters needed such as load, extraction steam pressure, heater drain temperature and inlet and outlet feed water temperature on a heater were collected on the Distributed Control System (DCS) at Central Control Room (CCR) station. Other necessary data like steam and drain enthalpies were collected using CATT 3 software or steam tables. There were five tests collected at random dates on each unit where it is in operation. The data result features like Temperature Terminal Difference (TTD), Drain Cooler Approach (DCA) and Temperature Rise (TR) across heater were indicators used to determine and evaluate each heaters performance. Extraction Steam Flow Requirement was also calculated for additional performance verification. The evaluation results at maximum load shows that Unit No.2 HPH1 and $\mathrm{HPH} 2$ has lower TTD $\left(4.35^{\circ} \mathrm{C}\right.$ and $3.39^{\circ} \mathrm{C}$ respectively) and DCA $\left(-0.37^{\circ} \mathrm{C}\right.$ and $14.68^{\circ} \mathrm{C}$ respectively) and a higher TR $\left(21.97^{\circ} \mathrm{C}\right.$ and $\left.46.94^{\circ} \mathrm{C}\right)$ were remarkably good. The results also showed that as the low-pressure heaters goes to the last stage heater (LPH4 to LPH7), the TTD was increased on all units. A highest TTD $\left(49.86^{\circ} \mathrm{C}\right)$ and lowest TR $\left(2.95^{\circ} \mathrm{C}\right)$ on Unit 1 were observed which could be quiet alarming and an indication of off design even at full load. The ranges between minimum and maximum load at $5 \%$ load intervals showed that HPH1 and HPH2 (TTD and TR) were proportional to the load while LPH4 and LPH5 (TTD) were inversely proportional to load adjustments on all units. The last stage heater, $\mathrm{LPH} 7$, on Units 1 and 2 poorly performed during the load adjustments with its TR maintained only around $4^{\circ} \mathrm{C}$ at any load is an indication of off design condition. A mathematical approach of non-linear regression was also simulated using MATLAB R2013A on each heater's TTD, DCA, TR and Extraction steam flow requirement to allow other researcher or performance engineer for future framework. Thus, the results of the tests regarding the performance of regenerative feed water heaters proves that last stage heaters mostly encounter off design and high-pressure heaters are the most efficient. Finally, based from the evaluation results, it recommends inspecting or improve the last stage heaters to prevent equipment breakdown and conduct more routine plant performance on regenerative feed water heaters to monitor the heaters degradation or improvement.
\end{abstract}

Keywords: Regenerative feed water heater; Off-design; Coal fired power plant (CFPP); Performance indicators; TTD; DCA; TR

\section{Introduction}

During the recent years in the island Mindanao, Philippines, people experience power shortage that leads rotating blackout at different area within. This makes electricity supply in the area scarce and power generating units on at peak load. The scarcity of power and increasing demand of electricity consumption leads the available generating power plants to play a vital role in operating at maximum level of efficiency and the best performance of its systems. One of the system that is in need to evaluate is the regenerative feed water heater system where most of thermal power plants have these designs.

A feed water heater system was based from the RegenerativeRankine Cycle principle of preheating feed water in order to increase efficiency [1-4]. Extracted Steam from each turbine stages are used to preheat the feed water going to the boiler at a series of stages. Thermal power plant was involved in this complex process in order to maintain and improve overall cycle efficiency. However, there are off design behaviors of each heater that needed to consider in such cases. Cases involves where load or power generated are below the maximum capacity $[5,6]$ or unit derating. During these situations, the heaters performance must be optimized and observe properly by the operator.

Performance evaluation of these sub systems, especially at the regenerative feed water heaters, is an important tool in the field of operations and engineering to monitor an equipment status or condition before a serious breakdown occurs. Several researchers have conducted the performance evaluation on closed feed water heaters at different power plants using ASME PTC 12.1 and Heat Exchange Institute Inc. as their guiding principles. The performance indicators such as Terminal Temperature Difference (TTD), Drain Cooler Approach (DCA) and Temperature Rise (TR) across heater were considered in evaluating a closed feed water heaters performance.

The newly built coal fired thermal power plant at the Mindanao Philippines last year 2016 with gross capacity of $3 \times 135 \mathrm{MW}$ is on its evaluation on feed water heaters performance. There was a much-sought

*Corresponding author: Almedilla JR, Department of Mechanical Engineering University of Science and Technology of Southern Philippines, CM Recto Avenue, Lapasan, Cagayan De Oro City, Philippines, Tel: +63888561738; E-mail: jsonalmedilla@gmail.com

Received May 23, 2018; Accepted June 03, 2018; Published June 08, 2018

Citation: Almedilla JR, Pabilona LL, Villanueva EP (2018) Performance Evaluation and Off Design Analysis of the HP and LP Feed Water Heaters on a $3 \times 135 \mathrm{MW}$ Coal Fired Power Plant. J Appl Mech Eng 7: 308. doi:10.4172/2168-9873.1000308

Copyright: (c) 2018 Almedilla JR, et al. This is an open-access article distributed under the terms of the Creative Commons Attribution License, which permits unrestricted use, distribution, and reproduction in any medium, provided the original author and source are credited. 
concern by the personnel involved to determine each of the heaters performance knowing that the power plant is operating at different load demand hourly. A possible off design condition exists on the feed water heaters system could show up and might -have significant bad effect for the generating unit in the future [6]. This study is about the determination of the heaters performance, both high and low-pressure feed water heaters of the $3 \times 135$ MW Coal Fired Power Plant.

\section{Materials and Methods}

\section{Regenerative-Reheat rankine cycle}

The cycle originates from the basic feed heating system for each process in a vapor power cycle where a hypothetical (or) ideal process Rankine Cycle which represents the basic intended operation by Cengel [3] of having four major processes. The processes involve are the ideal constant pressure heat addition to boiler, reversible adiabatic expansion at turbine, constant pressure heat rejection in condenser and reversible adiabatic compression on feed pump.

In the Regenerative-Reheat, both the features of reheating steam back to boiler and regenerative preheating of feed water by the heaters were used in order to attain a higher efficiency and moisture free steam at low pressure turbines [1-4]. The reheating of steam also increases the efficiency of the process and maintaining a superheated steam while regenerative heaters preheat feed water to a certain temperature thereby slightly reducing the fuel consumption. The number of regenerative heaters is arranged in a series of stages, high pressure, and low-pressure part, where the steam drain is cascaded normally at the downstream heater.

\section{Closed feed water heaters and open feed water heater}

Regenerative feed water heaters are always used in steam power plants to improve efficiency. They can be classified into two types; Closed and Open type. Both these types of heaters are used by Nag [2] where each may have different process in preheating but almost same principle. The heaters can be classified according to the source of extraction. High pressure heaters extract steam from high pressure turbine while low pressure heaters extract steam from either intermediate or low-pressure turbine.

Closed Feed Water Heaters are shell and tube type heat exchangers where steam and water do not mix. The shell side is where the bled or extracted steam flows while the tube side is the preheated feed water. The number of closed type heaters depends on the capacity of the unit.

Open Type or Direct Contact Feed Water Heaters is another type of regenerative heaters. The extraction steam is mixed directly with the incoming sub-cooled feed water where the mixture becomes saturated water at the extraction steam pressure [1]. This type of heater only uses $\mathrm{TR}$ as its performance indicator.

\section{Experimental Set-Up Description}

The system set up is the High Pressure and Low Pressure regenerative feed water heater system of a newly built coal fired power plant located in Mindanao, Philippines. It has a gross capacity of $3 \times 135$ MW with seven extraction stages of which composed of two vertical $\mathrm{HPH}$, four vertical LPH and one tray type Deaerator Feed Water Storage Tank Heater (DEA) in each unit identical. The Figure 1 above shows the schematic process and location of instruments involved for the study. High Pressure Heaters extract steam from the high-pressure turbine while the Deaerator Heater and Low-Pressure Heaters extract steam from Intermediate pressure turbine and low-pressure turbine.
The stages of feed water preheating process per unit according to extraction stages is as follows; HPH1, HPH2, DEA, LPH4, LPH5, LPH6 and LPH7.

The extraction steam pressure and temperature were installed in each stage for data monitoring of the system as well as its heater drain temperature. Feed water inlet and outlet temperatures were also available in the set-up. Water level were also equipped in each heater. The heaters drain system and control valves are manipulated by the Distributed Control System (DCS) at the Central Control Room Station (CCR). Previous data and parameters available at DCS can be historically reviewed at its historian.

The test will be composed of 5 test trials at $5 \%$ load interval between minimum $(30 \%$ or $40.5 \mathrm{MW})$ and maximum $(100 \%$ or $135 \mathrm{MW})$ load capacity ranges in each unit in a random date which the unit is in operation. The data needed in each heater are the load, extraction pressure, heater drain temperature, and inlet and outlet feed water temperatures. Other data are available on steam tables. These data and parameters will be used for collection and gathering during the evaluation to generate the results in an average value. For the purpose of the analysis, the system is said to be carried out in a steady flow operation, applying steady state steady flow (SSSF) thermodynamic -equations on each process neglecting changes in kinetic and potential energy.

\section{Data Analysis and Evaluation of Performance}

The data gathered and collected from the experiment and the other data plotted from steam table or CATT 3 will be used for tabulation of results [7-11]. These results are the performance indicators recommended by the American Society of Mechanical Engineers Performance Test Code 12.11978 - 2017 and Heat Exchange Institute Incorporated [12-14]. These indicators were used by previous studies in evaluation of regenerative feed water heaters [5-9].

The Terminal Temperature Difference (TTD) is used to provide feedback on the heaters performance relative to heat transfer. An increase in TTD indicates a reduction in heat transfer while a decrease indicates an improvement [6].

$$
T T D=T \text { sat }-T(\text { fwout })
$$

The Drain Cool Approach (DCA) is a method used to infer feed water heater level based on temperature difference. It is the difference between drain outlet temperature and feed water inlet temperature [12].

$$
D C A=T(d)-T(\text { fwin })
$$

The Temperature Rise across heater (TR) is a method used to determine how much the heater has inc reased the temperature of the feed water [14]. A high TR could indicate a good heat transfer for a heater.

$$
T R=T(\text { fwout })-T(\text { fwin })
$$

The extraction steam flow requirement $\left(\mathrm{m}_{\text {ext }}\right)$ may be included to this study for more analysis as an improved method for trending heater performance $[4,11]$. The extraction steam flow is said to self-regulating where steam flow is dependent on the operating pressure of the turbine at load ranges.

$$
m_{\text {ext }}=\frac{m_{f w}\left(C_{p}\right)\left(T_{\text {fwout }}-T_{\text {fwin }}\right)+m_{\text {drain in }}\left(h_{\text {drain out }}-h_{\text {drain in }}\right)}{h_{\text {ext }}-h_{\text {drain out }}}
$$

where, $\mathrm{T}(\mathrm{sat})=$ steam saturation temperature. 


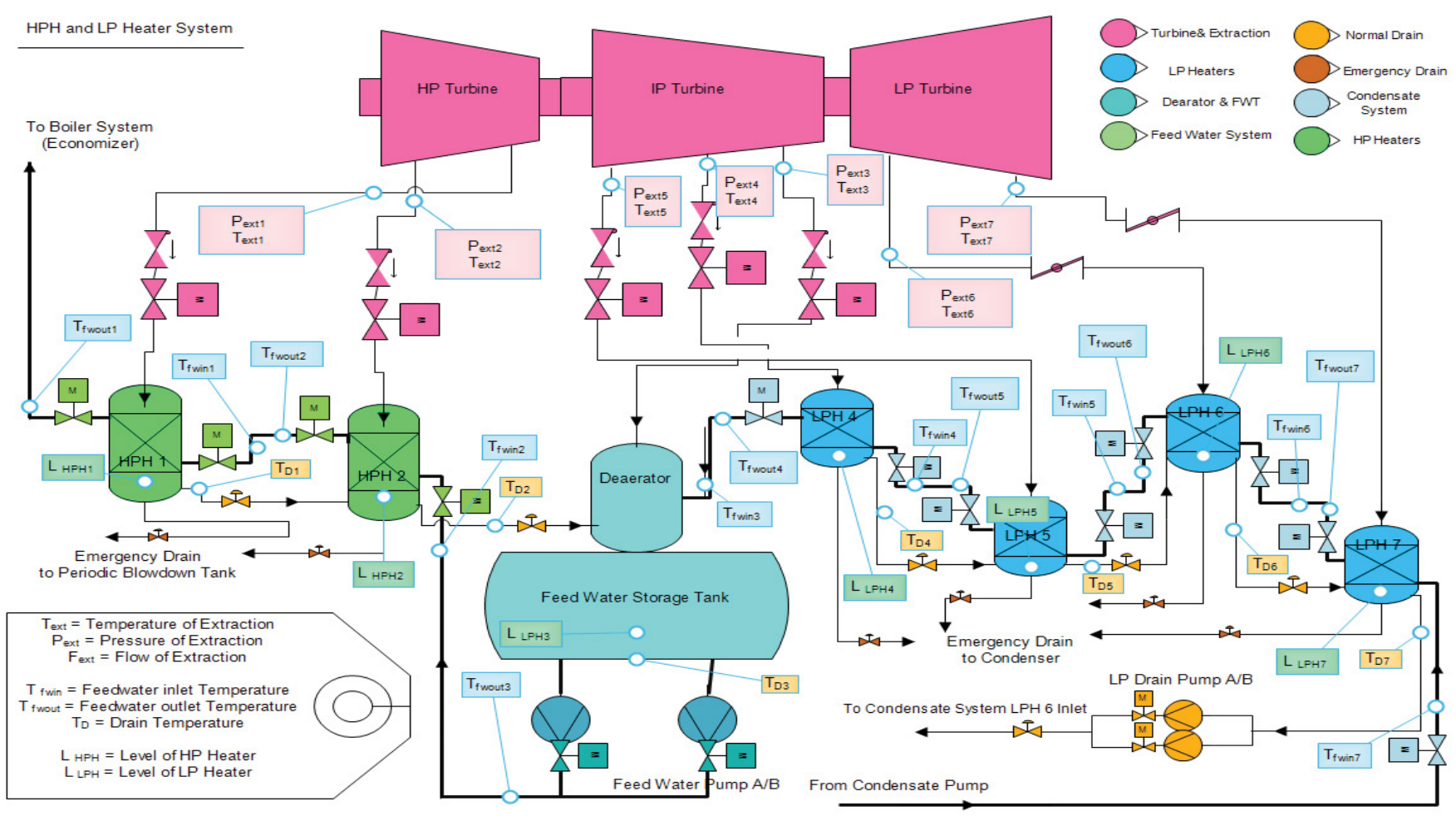

Figure 1: Experiment system set-up process flow with instrument locations.

$\mathrm{T}(\mathrm{fwout})=$ feed water outlet temperature.

$\mathrm{T}(\mathrm{f}$ win $)=$ feed water inlet temperature.

$\mathrm{T}(\mathrm{d})=$ heater drain temperature.

$\mathrm{m}_{\mathrm{fw}}=$ feed water mass flow rate

$\mathrm{m}_{\text {drain in }}=$ drain inlet flow rate of previous heater

$\mathrm{C}_{\mathrm{p}}=$ specific heat of the feed water

$\mathrm{h}_{\text {drain out }}=$ enthalpy of drain outlet

$\mathrm{h}_{\text {drain in }}=$ enthalpy of drain inlet

$\mathrm{h}_{\text {ext }}=$ enthalpy of extraction steam

These TTD, DCA and TR features will be used to determine a closed feed water heater performance. Extraction steam flow requirement is an additional result for further investigation and evaluation. Thus, the five test results per unit can be used for mathematical modelling using nonlinear regression.

\section{Results and Discussions}

\section{Maximum load performance results on each units}

The Figure 2 above shows the designed performance of each heaters according to the Heat Balance Design. It shows zero TTD at both HPH1 and $2.8^{\circ} \mathrm{C}$ for LPH4, LPH5 and LPH6 while $2.2^{\circ} \mathrm{C}$ in last stage (LPH7). The DCA must be $5^{\circ} \mathrm{C}$ for HPH1, LPH4 LPH5 and LPH6 while HPH2 is around $8.2^{\circ} \mathrm{C}$. The last stage heater has no data for DCA since the design shows that drain water from LPH7 re-enters the outlet of LPH7 feed water line at a same temperature. The TR also shows that all heaters must have at least $20^{\circ} \mathrm{C}$ rise. $\mathrm{HPH} 2$ design TR is higher ranged around $41.7^{\circ} \mathrm{C}$.
The Figure 3 shows the Unit 1 performance factor average results of heaters at maximum load 135MW. It appears that high pressure heaters are shown to be near the design performance while the lowpressure heaters show differences on performance indicators especially at the last stage with high TTD $49.6^{\circ} \mathrm{C}$ but low TR $2.95^{\circ} \mathrm{C}$ in average. The same result also happens on V. Bode [9] where one unit also has high TTD. The TTD for high pressure heaters, both HPH1 and HPH2, performed near the designed TTD of $5^{\circ} \mathrm{C}$ where it reached $6.23^{\circ} \mathrm{C}$ and $3.42^{\circ} \mathrm{C}$, respectively. Its DCA were also very low compared to the design. The TR are also within the ranges and almost comparatively same on the design. The DEA heater TR appeared to average around 38.99 were within near design values.

On the low-pressure heaters, the LPH4 and LPH5 has also near values to the designed $\operatorname{TTD}\left(5.94^{\circ} \mathrm{C}\right.$ and $9.47^{\circ} \mathrm{C}$, respectively) but the last two stage heaters were very high spiking around $22.01^{\circ} \mathrm{C}$ and $49.86^{\circ} \mathrm{C}$ respectively for LPH6 and LPH7. The DCA also was quite high on the low-pressure heaters where LPH4, LPH5, LPH6 and LPH7 with $12.03^{\circ} \mathrm{C}, 26.69^{\circ} \mathrm{C}, 29.53^{\circ} \mathrm{C}$ and $15.53^{\circ} \mathrm{C}$ respectively. The TR for the last 3 low pressure heaters LPH4, LPH5 and LPH6 also resulted to near its designed levels. However, on the last stage heater, the poor TR of $2.95^{\circ} \mathrm{C}$ at $\mathrm{LPH} 7$ shows it poorly performed. Its high TTD and TR results reveals that the last stage heater encounters off design conditions even at maximum load 135MW. In brief, the high-pressure heaters performed the best while the two low pressure heater LPH4 and LPH5 normally functions to its design level.

The Figure 4 above is the average result of Unit 2 performance test on heaters under maximum load. High TTD and DCA $38.53^{\circ} \mathrm{C}$ and $15.98^{\circ} \mathrm{C}$, respectively with low TR $6.66^{\circ} \mathrm{C}$ on $\mathrm{LPH} 7$ is a badly indication of poor performance similar to that of Bode [10]. The high-pressure heaters, HPH1 and HPH2, shows a good performance of the equipment 


\section{Design Performance Factors according to Heat Balance}

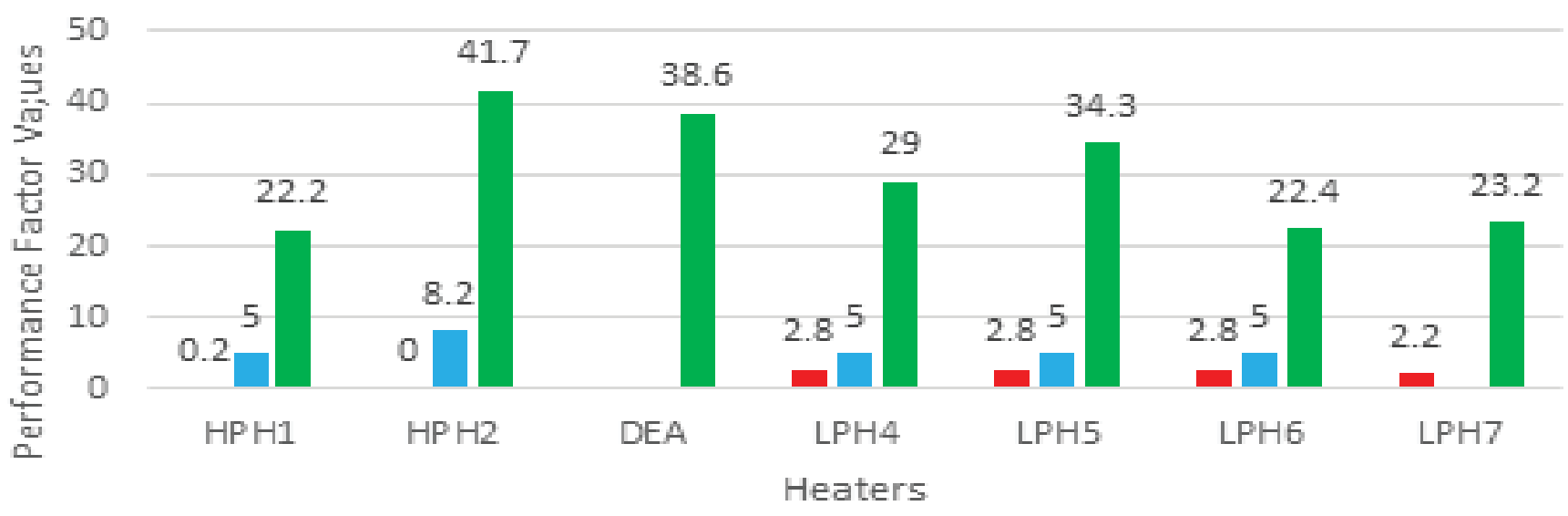

TTD $\square$ DCA $\square$ TR

Figure 2: Performance according to heat balance design.

\section{Unit 1 Heaters Performance Factors}

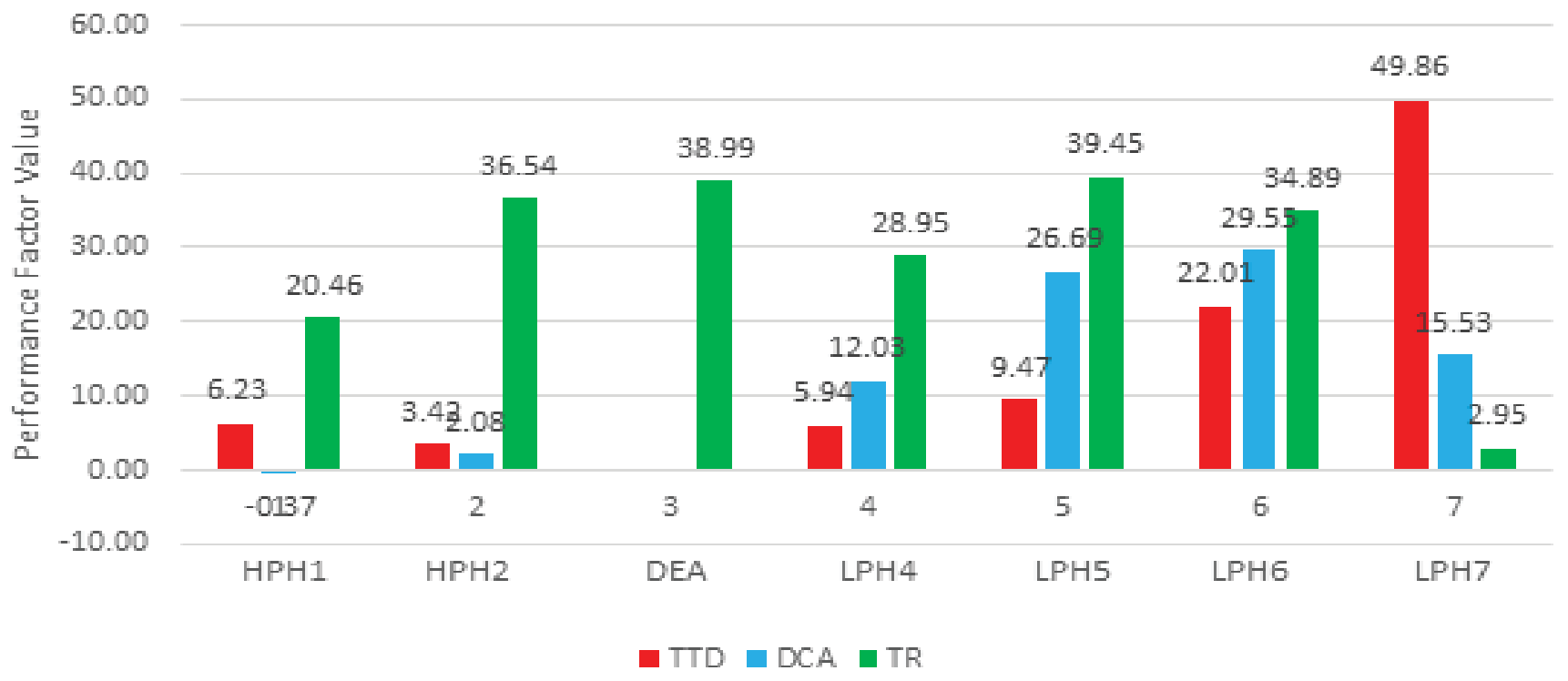

Figure 3: Unit 1 performance result $135 \mathrm{MW}$

where the TTD $21.97^{\circ} \mathrm{C}$ and $46.94^{\circ} \mathrm{C}$ respectively. Its DCA were also low especially at the first stage heater. The TR was remarkably very high specially on the $\mathrm{HPH} 2$ reaching to around $46.94^{\circ} \mathrm{C}$ however could also be a disadvantage where it could lead to stressing of the internal parts. The DEA heater was the same on its design value.

The low-pressure heaters LPH4 and LPH5 also shows a slightly high TTD $6.11^{\circ} \mathrm{C}$ and $9.27^{\circ} \mathrm{C}$ respectively but can be considerable. Its DCA were also quite high of around $13.29^{\circ} \mathrm{C}$ and $25.38^{\circ} \mathrm{C}$ compared to the design. But on its TR it showed within near the design values. We can say that these two heaters fairly performed. However, on the two last stage heaters LPH6 and LPH7, the TTD were very high of peaking around $24.24^{\circ} \mathrm{C}$ and $38.53^{\circ} \mathrm{C}$ respectively. Its DCA were also very high of around $28.40^{\circ} \mathrm{C}$ and $15.98^{\circ} \mathrm{C}$ respectively. The TR on last stage has a rise of only around $6.6^{\circ} \mathrm{C}$. The high TTD, DCA and low TR reveals that the Unit 2 last stage heater LPH7 also encountered off design conditions even at maximum load operations.

The Figure 5 shows the average results of Unit 3 performance indicators on its heaters. It shows similar results on the early stage 


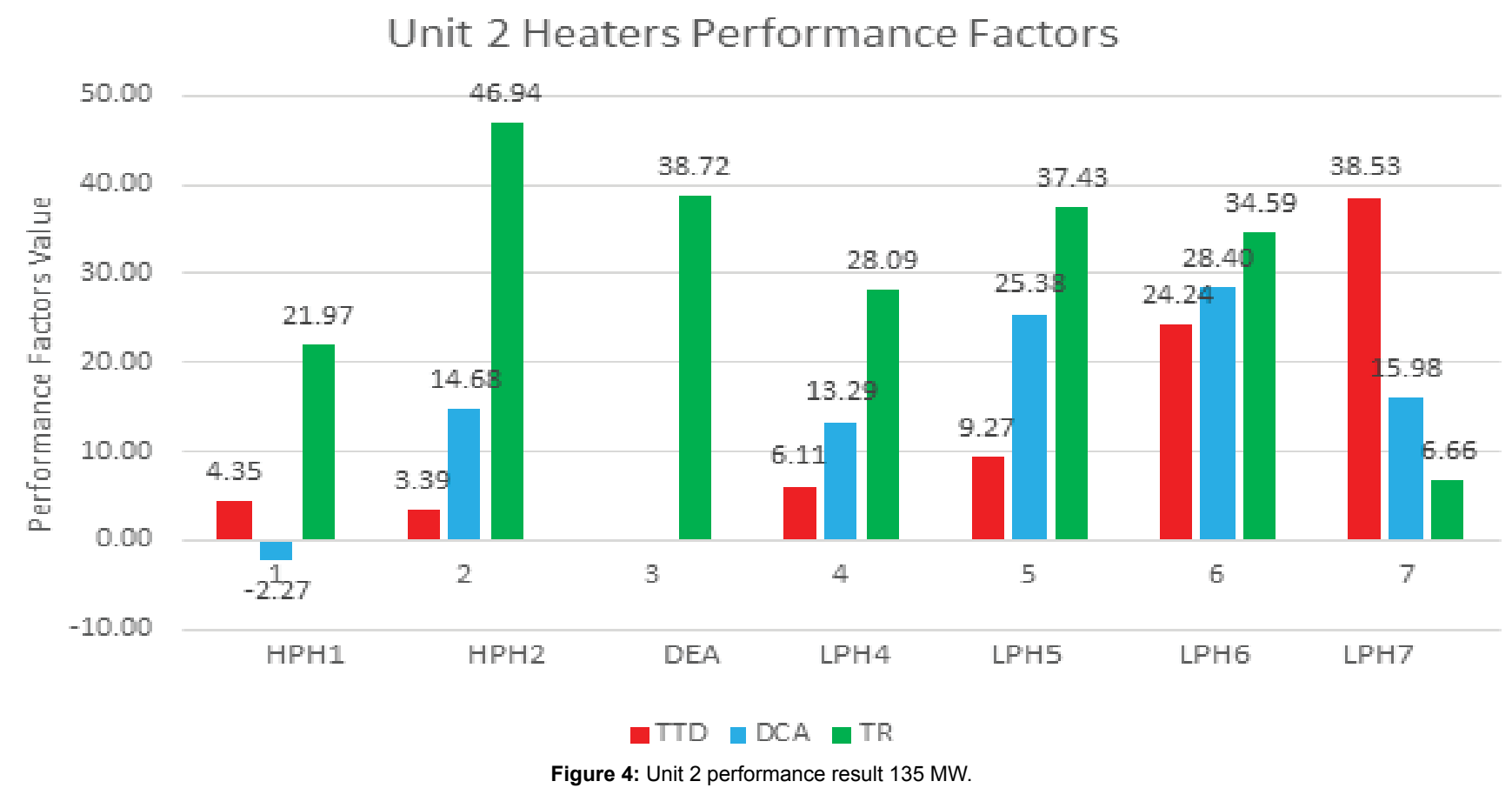

Figure 4: Unit 2 performance result $135 \mathrm{MW}$.

\section{Unit 3 Heaters Performance Factors}

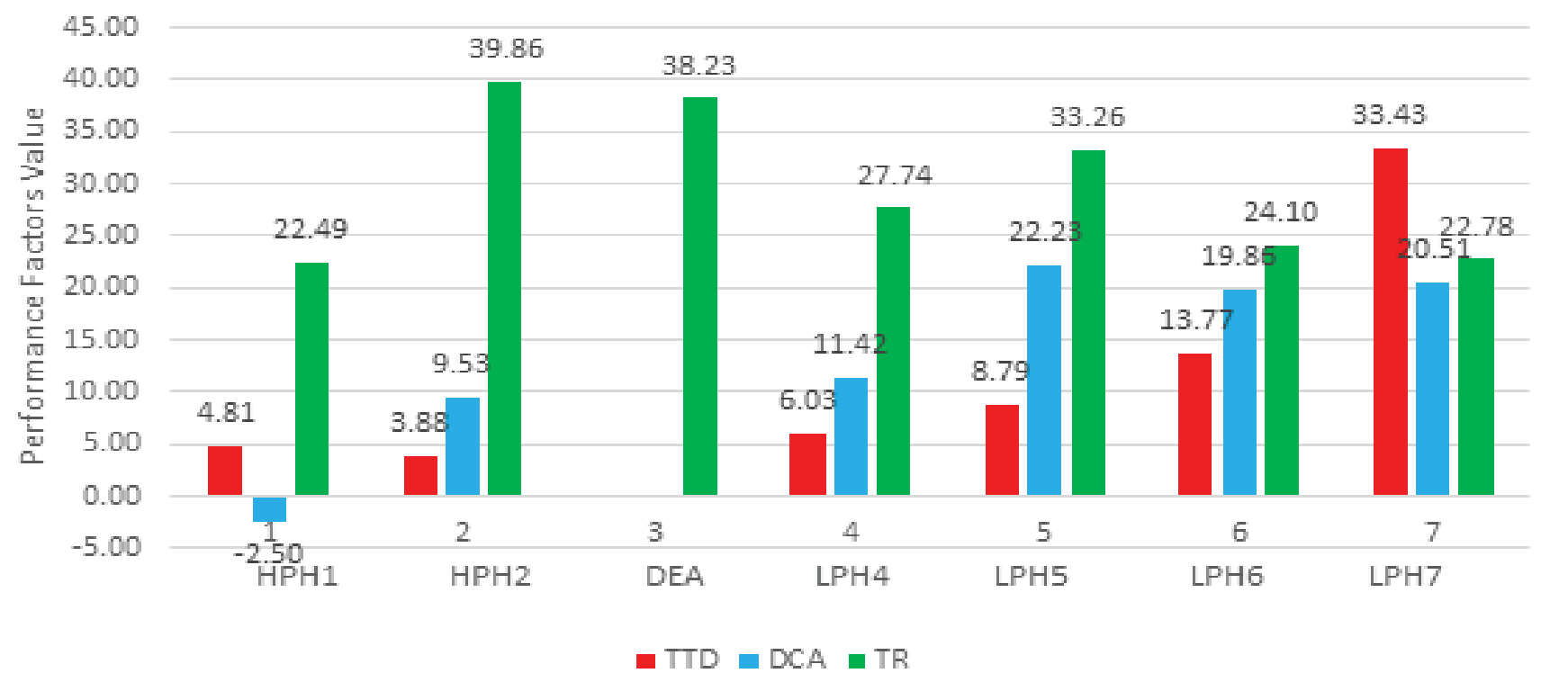

Figure 5: Unit 3 performance result $135 \mathrm{MW}$.

heaters with the other units. However, the last stage heater was found to be better since it shows slightly lower TTD $33.43^{\circ} \mathrm{C}$ compared to other units and high TR $22.78^{\circ} \mathrm{C}$.

High TTD and DCA could mean that water level may not be proper. Significance of heater level was discussed on previous studies [7-9]. The high-pressure heaters HPH1 and HPH2 TTD of $4.81^{\circ} \mathrm{C}$ and $3.88^{\circ} \mathrm{C}$ which were below the design values is an indication of a good performance. The DCA were also very low and its TR $22.49^{\circ} \mathrm{C}$ and $39.86^{\circ} \mathrm{C}$ were also within near the design values. The DEA heater also was remarkably at its design value $38.23^{\circ} \mathrm{C}$.

On the low-pressure heaters LPH4 and LPH5, both TTD $\left(6.03^{\circ} \mathrm{C}\right.$ and $8.79^{\circ} \mathrm{C}$ respectively) and DCA $\left(11.42^{\circ} \mathrm{C}\right.$ and $22.23^{\circ} \mathrm{C}$ respectively) were considerably near the design ranges. With the $\mathrm{TR}\left(27.74^{\circ} \mathrm{C}\right.$ and $33.26^{\circ} \mathrm{C}$ respectively) these early two low pressure heaters also revealed fairly performed at maximum load 135MW. The two last stage heater LPH6 and LPH7, although ah high TTD $\left(13.77^{\circ} \mathrm{C}\right.$ and $33.43^{\circ} \mathrm{C}$ respectively) and DCA $\left(19.86^{\circ} \mathrm{C}\right.$ and $20.51^{\circ} \mathrm{C}$ respectively) but also has 
Citation: Almedilla JR, Pabilona LL, Villanueva EP (2018) Performance Evaluation and Off Design Analysis of the HP and LP Feed Water Heaters on a 3 × 135 MW Coal Fired Power Plant. J Appl Mech Eng 7: 308. doi:10.4172/2168-9873.1000308

Page 6 of 14

fair rise in $\operatorname{TR}\left(24.1^{\circ} \mathrm{C}\right.$ and $22.78^{\circ} \mathrm{C}$ respectively) indicates also a fair performance.

In general, the test for full load (135 MW) on all units showed that high pressure heaters HPH1 and $\mathrm{HPH} 2$ were performing efficient and in good condition. LPH4 and LPH5 were fairly performing due to TTD were within near the design but DCA were high. The last stage heater (LPH7) on units 1 and 2 were performing worse due to high TTD and low TR. Also, a high DCA at that heater could possibly mean that the heater drain had not transferred heat energy to the feed water properly due to incorrect water level on heater. However, the high drain temperature on the LPH7 were recovered since it was mixed with the incoming feed water inlet to LPH6.

\section{Load adjustment performance test}

TTD results: The Figure 6 revealed the results for the high-pressure steam source heaters HPH1 and HPH2 on the units 1,2 and 3. The TTD on all heaters in a unit both HPH1 and HPH2 were proportional to the load adjustment. This means that the lower the load (power output) the lower the TTD it operates and vice versa. Unit $1 \mathrm{HPH} 2$ showed the highest TTD from $\left(2.5^{\circ} \mathrm{C}\right.$ to $\left.6.2^{\circ} \mathrm{C}\right)$ trend characteristic during the test while the Unit $2 \mathrm{HPH} 2$ has the lowest TTD trend $\left(0.2^{\circ} \mathrm{C}\right.$ to $3.4^{\circ} \mathrm{C}$ ). The Figure 7 showed the TTD for intermediate pressure turbine extraction steam source of LPH4 and LPH5. Its TTD shows that early low load operations has higher TTD for the two heaters in the unit but somehow decreases and maintained for LPH4 and LPH5 $\left(10^{\circ} \mathrm{C}\right.$ and $6{ }^{\circ} \mathrm{C}$

\section{HPH1 \& HPH2 TTD vs Load}
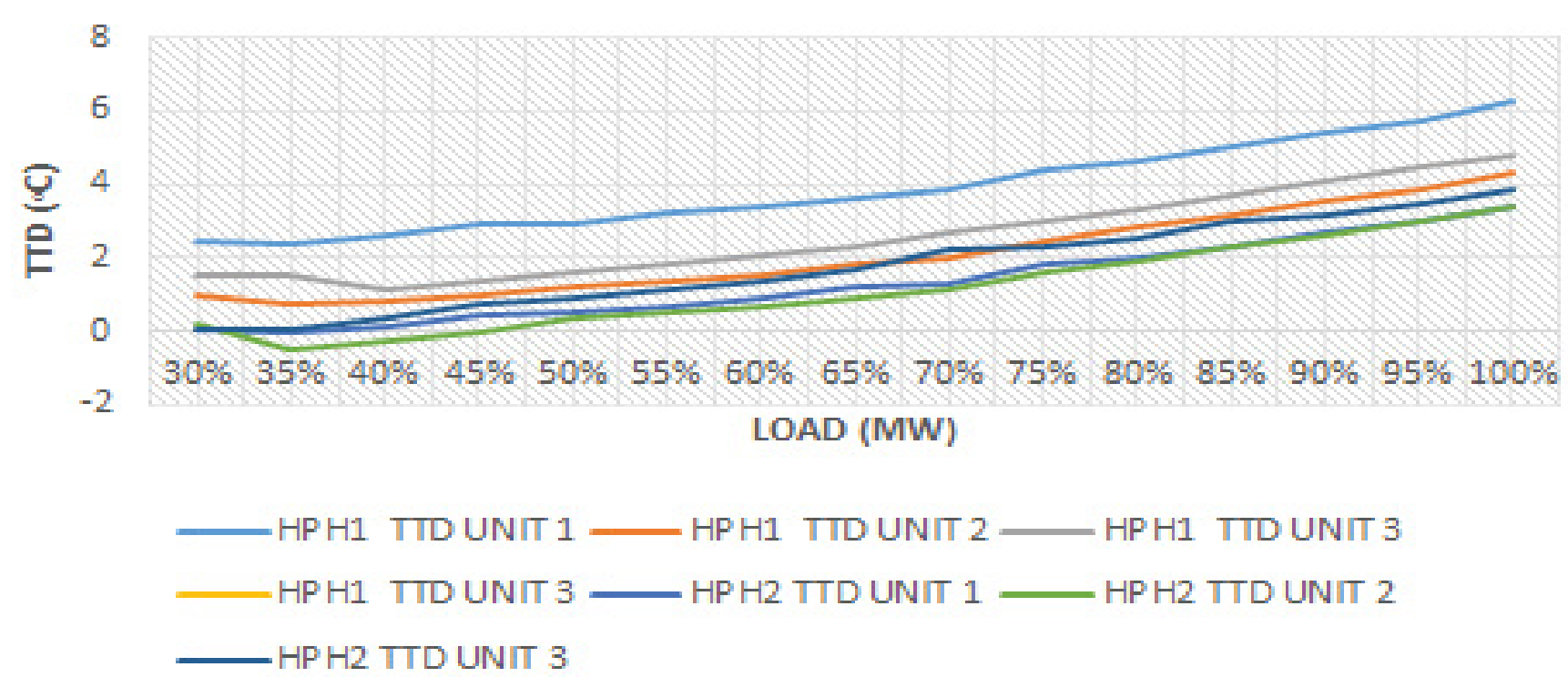

Figure 6: HPH1 and HPH2 TTD vs. load trend.

\section{LPH4 \& LPH5TTD vs Load}
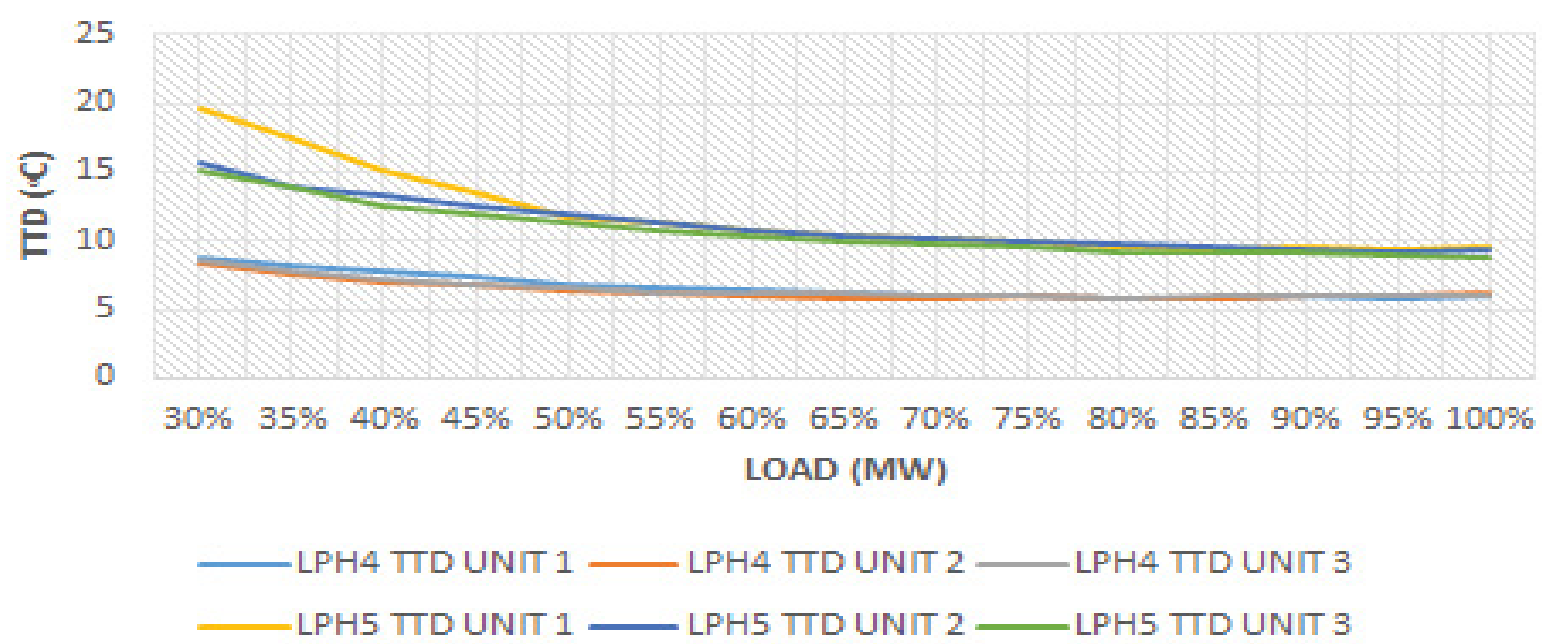

Figure 7: LPH4 and LPH5 TTD vs. load trend. 
Citation: Almedilla JR, Pabilona LL, Villanueva EP (2018) Performance Evaluation and Off Design Analysis of the HP and LP Feed Water Heaters on a $3 \times 135$ MW Coal Fired Power Plant. J Appl Mech Eng 7: 308. doi:10.4172/2168-9873.1000308

Page 7 of 14

respectively) at higher load. Unit 1 LPH5 has the highest TTD $\left(20^{\circ} \mathrm{C}\right)$ at minimum load but later maintained similarly with the other units LPH5. We can fairly say that these two heater, LPH4 and LPH5, has similar performance with other Units. The Figure 8 revealed the TTD performance of the last two low pressure heaters LPH6 and LPH7. In the trend, we can see that the last stage heater, LPH7 was quite erratic compared with the other units. This is possibly because of Unit 1 and Unit 2 off design condition at any load during the previous full load test. LPH6 for the units results almost near with each other units. A good indication of performance must show that the trending is going down at load increment like the Unit $3 \mathrm{LPH} 7$ having the lowest TTD $\left(33.4^{\circ} \mathrm{C}\right)$ among the last stage heaters. In summary, high pressure heaters TTD increases as the load adjustment was increased. The low-pressure heaters LPH4, LPH5 and LPH6 has a decreasing trend characteristic at load increment while the last stage heater LPH7 was unique at each unit.

DCA results: The Figure 9 showed the high-pressure heater HPH1 and HPH2 DCA results of the three unit. The results show that the first stage heater, HPH1, has values of DCA below zero and stable at any load adjustments. On $\mathrm{HPH} 2$, the Unit 2 has the highest DCA on the highpressure part reaching $12^{\circ} \mathrm{C}$ to $14.7^{\circ} \mathrm{C}$ while Unit $1 \mathrm{HPH} 2$ has the lowest $\left(0^{\circ} \mathrm{C}\right.$ to $\left.3.4^{\circ} \mathrm{C}\right)$. On the Figure 10 , it showed the trend characteristics of LPH4 and LPH5, intermediate pressure turbine extraction source, where the DCA becomes stable as the load increases. LPH4 on the three units was stable around $12^{\circ} \mathrm{C}$ to $14^{\circ} \mathrm{C}$ as load increased. And LPH5 was also stable around $22^{\circ} \mathrm{C}$ to $27^{\circ} \mathrm{C}$ as load increases. The DCA values on both heaters was slightly higher compared to the designed value at full load during previous results discussed at 7.1. Finally, on the Figure 11 revealed the trend characteristics results of the three units on LPH6 and LPH7. The DCA on both the two last stage heaters both slightly increased when load was increased except for Unit 3 LPH6. This was because of the possibility of LPH6 drain cascading to the LPH7 efficiently and LPH7 no off design conditions exists compared to the Units 1 and 2. In summary, a lower DCA indicates that the heater drain temperature is nearer from its inlet feed water temperature [12-14].
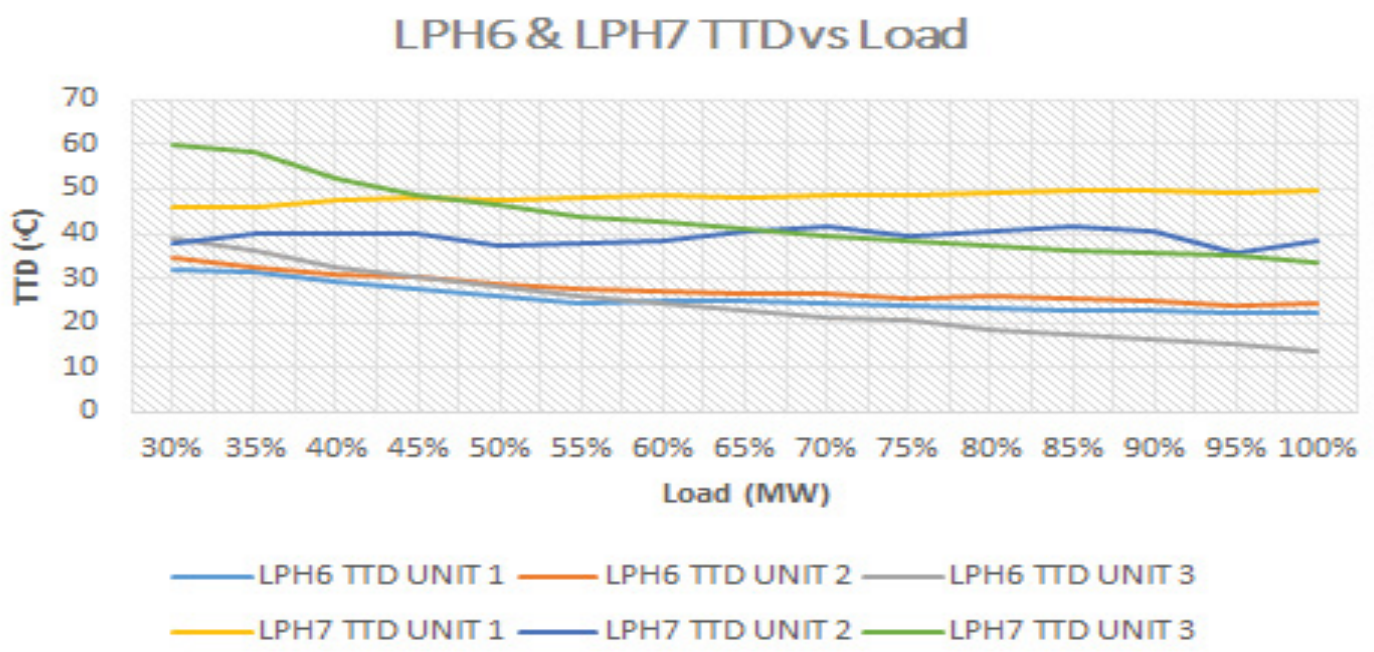

Figure 8: LPH6 and LPH7 TTD vs. load trend.

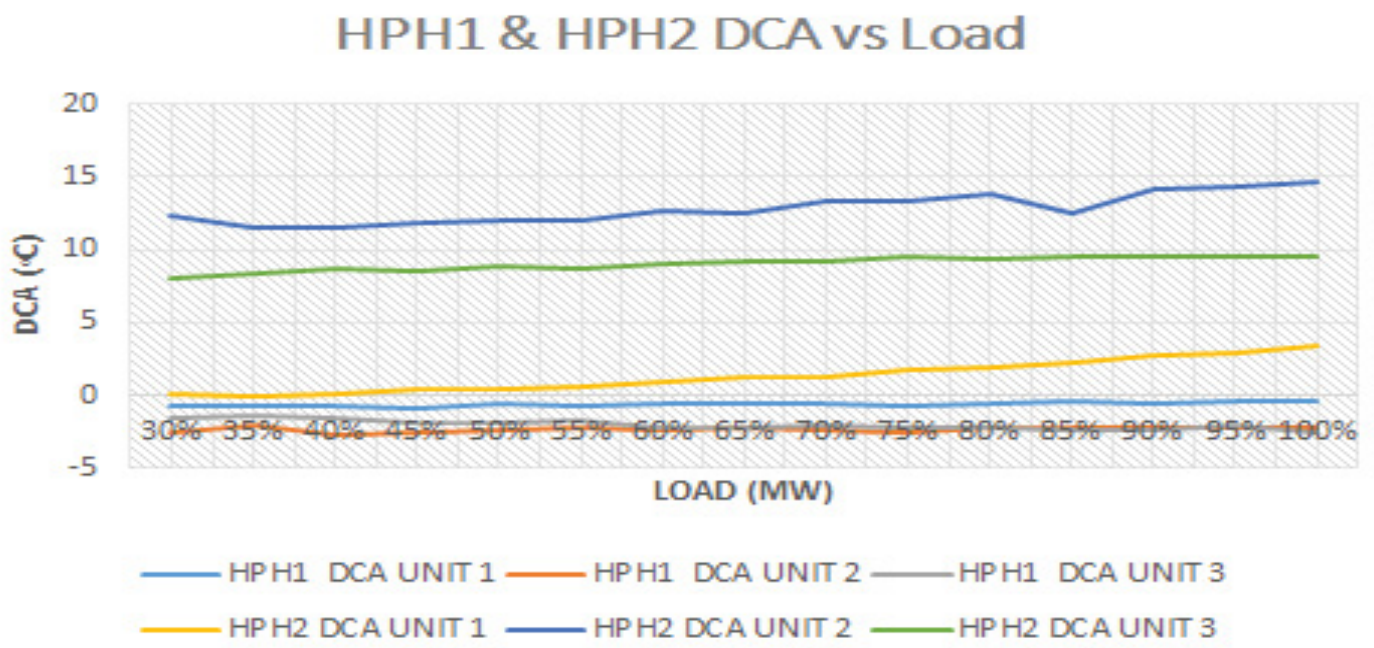

Figure 9: HPH1 and HPH2 DCA vs. load trend. 

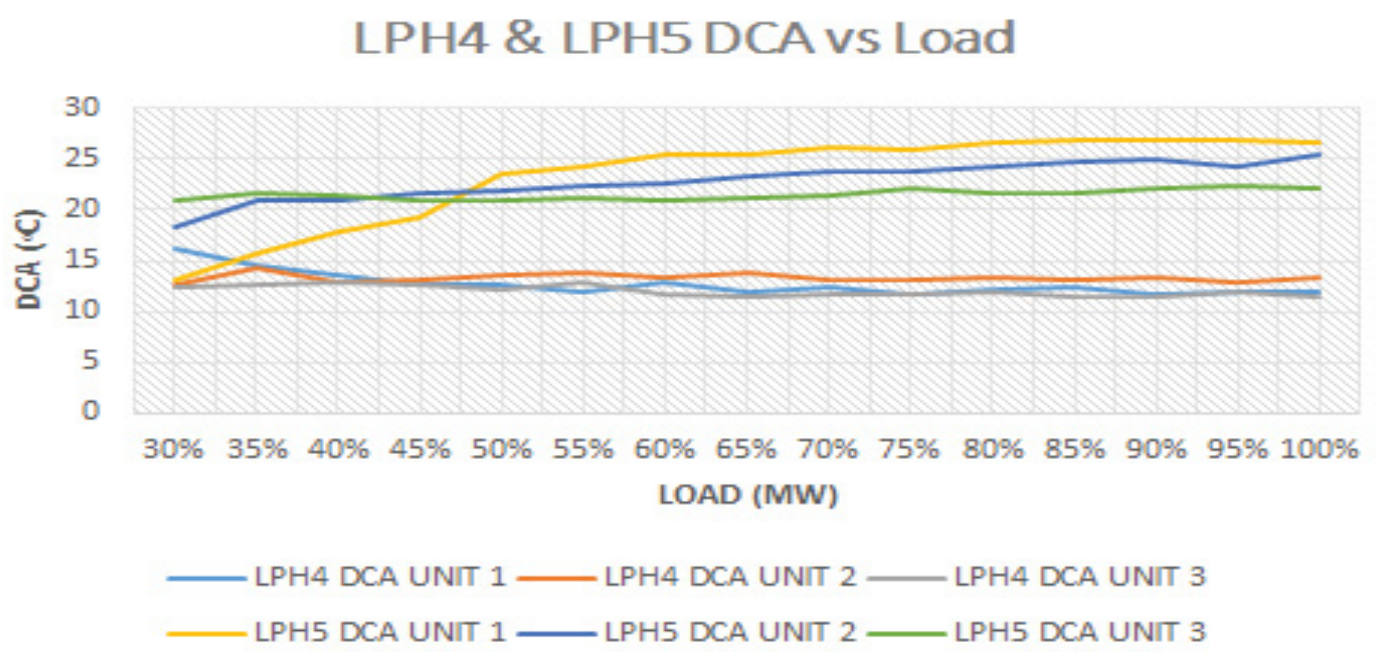

Figure 10: LPH4 and LPH5 DCA vs. load trend.

\section{LPH6 \& LPH7 DCA vs Load}
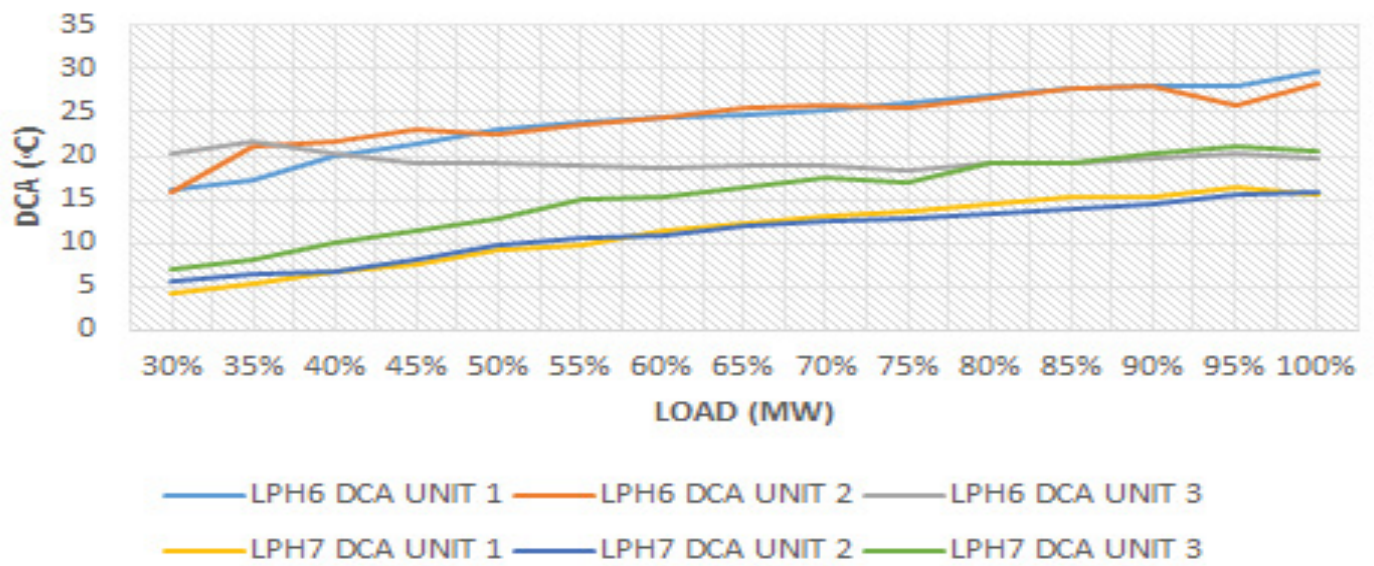

Figure 11: LPH6 and LPH7 DCA vs. load trend.

Most units' HPH2, LPH5 and LPH7 has higher DCA indicating that its drain temperature may not properly utilized or absorbed. However, the DCA is also related to the water drain level as mentioned earlier. A proper heater level must be observed or tested to optimized heat transfer at sub-cooling zone inside the heater [6].

Temperature Rise (TR) across heater results: The Figure 12 showed the results of high pressure heaters HPH1 and HPH2 Temperature Rise (TR) trend characteristics. The HPH1 on the three units significantly maintained a rise of at least $20^{\circ} \mathrm{C}$ during load adjustments. The $\mathrm{HPH} 2$ somehow have different TR on each unit but also shows a slight significant increase in TR. The highest HPH2 TR operates at the Unit 2 of around $40^{\circ} \mathrm{C}$ to $47^{\circ} \mathrm{C}$ while Unit $1 \mathrm{HPH} 2$ has the lowest of only around $32^{\circ} \mathrm{C}$ to $37^{\circ} \mathrm{C}$ as load was increased. On the DEA heater, the Figure 13 showed the results of the test on the three units. It somehow shows that the three units significantly increased, from around $30^{\circ} \mathrm{C}$ to $39^{\circ} \mathrm{C}$, during the load increment. The design at full load is around 38.6 based from the previous discussions at 7.1. This means that the DEA heaters on the three units fairly and significantly increases with around the same performance values which is near the design as the load increases. There were also no problems occurred during the tests. It is also important to keep in mind that this type of heater already receives steam via the common header during pre-start-up of a unit. This is because it is essential to remove non-condensable gases $\left(\mathrm{CO}_{2}\right.$, $\mathrm{O}_{2}, \mathrm{~N}_{2}$ etc.) prior to online of the equipment to maintain good water quality. That is why the starting TR was around $30^{\circ} \mathrm{C}$.

On the Figure 14, it showed the results of trend characteristics on the low-pressure heaters LPH4 and LPH5 Temperature Rise (TR). The results show a same gradual increase in TR at all LPH4 units from around $23^{\circ} \mathrm{C}$ to $29^{\circ} \mathrm{C}$. The LPH5 shows slight different values at each unit but same trend characteristics as load was increased. The highest TR on LPH5 was on the Unit $1\left(26^{\circ} \mathrm{C}\right.$ to $\left.40^{\circ} \mathrm{C}\right)$ while the lowest on Unit $3\left(28^{\circ} \mathrm{C}\right.$ to $\left.33^{\circ} \mathrm{C}\right)$. The increase in TR at each of these heaters in a unit means an improvement during load increment.

Finally, on the Figure 15 revealed the results of the last two low pressure heaters LPH6 and LPH7 TR. As expected from the results 


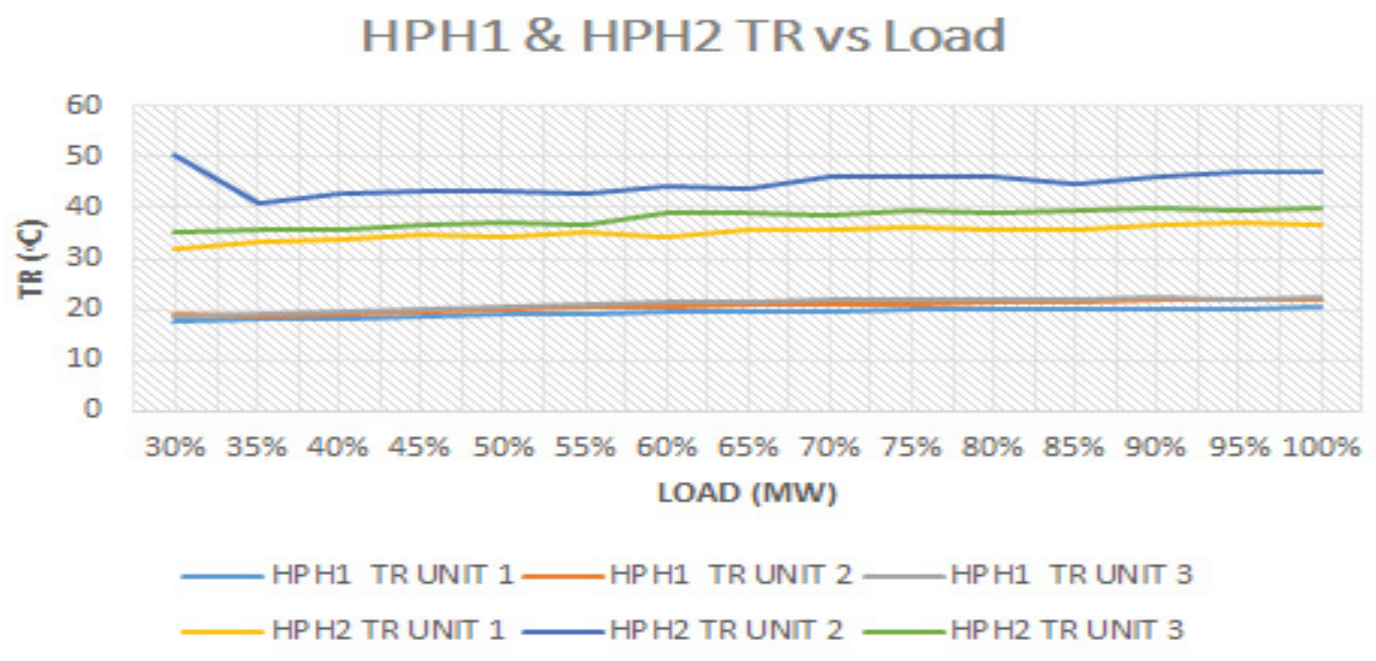

Figure 12: $\mathrm{HPH} 1$ and $\mathrm{HPH} 2 \mathrm{TR}$ vs. load trend

\section{DEA vs Load}

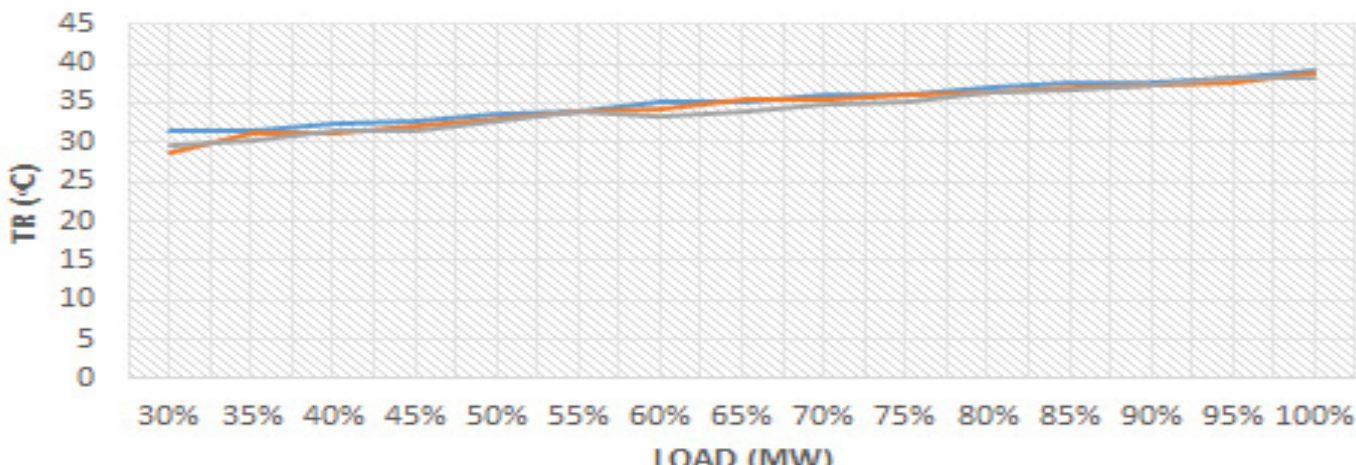

LOAD (MW)

Figure 13: DEA vs. load trend.

\section{LPH4 \& LPH5TR vs Load}

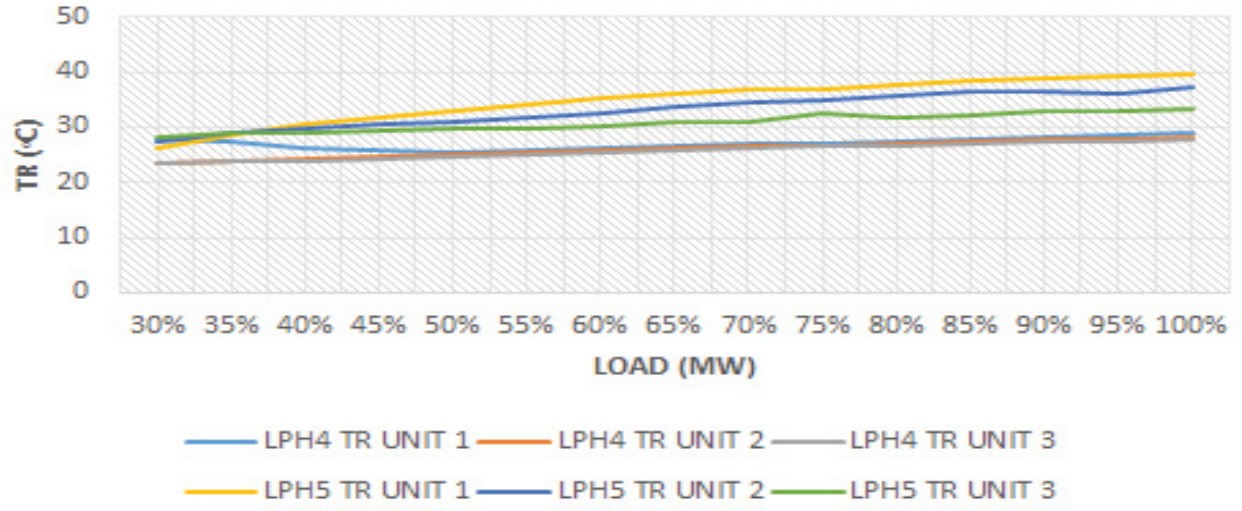

Figure 14: LPH4 and LPH5 vs. load trend. 


\section{LPH6 \& LPH7TR vs Load}

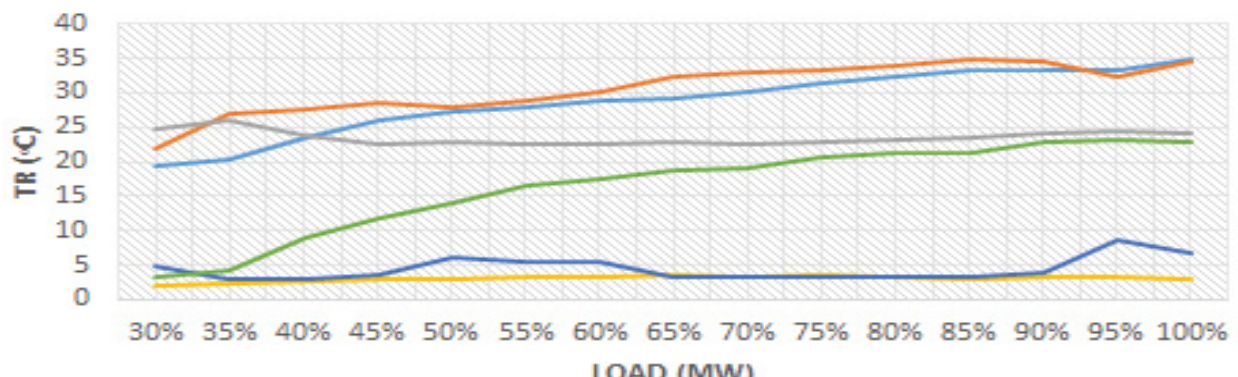

LOAD (MW)

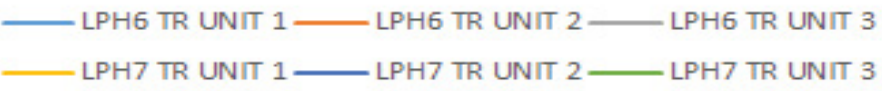

Figure 15: LPH6 and LPH7 vs. load trend.

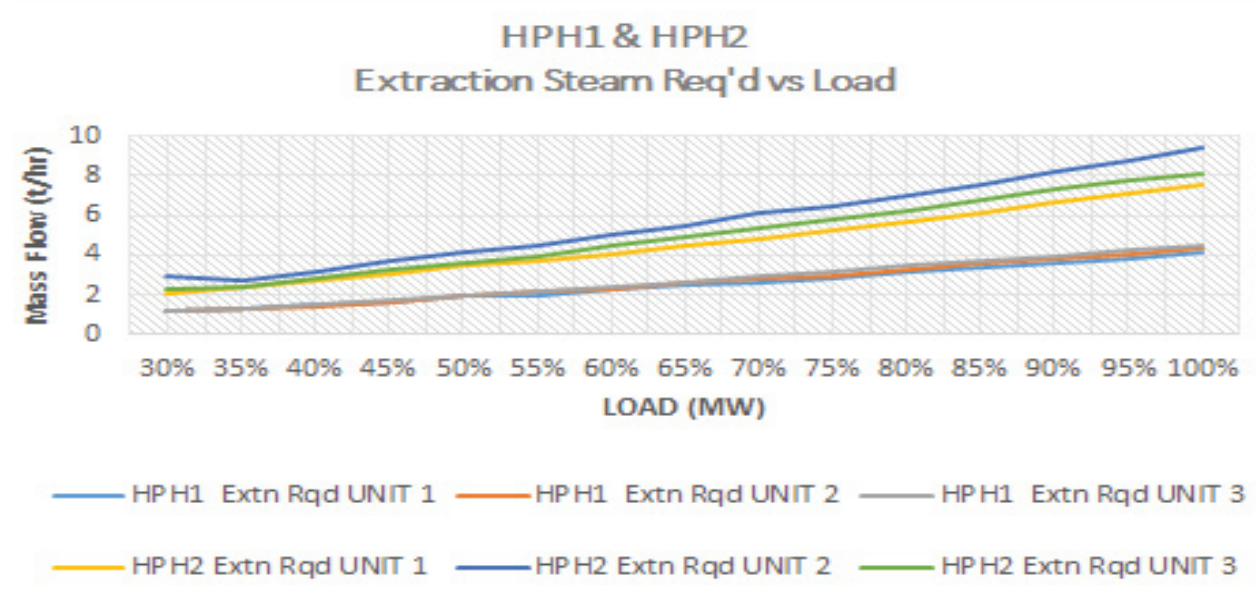

Figure 16: $\mathrm{HPH} 1$ and $\mathrm{HPH} 2$ extraction steam flow required.

discussed to 7.1, the TR of Unit 1 and Unit 2 encounters off design at any load making the LPH7 of the said unit has a very low TR. The trend characteristics above shows that the lowest TR was on the Unit 1 (maintained around $4^{\circ} \mathrm{C}$ ) while Unit 2 has rather an erratic increase in TR but somehow still very low $\left(8^{\circ} \mathrm{C}\right.$ highest on Unit $\left.2 \mathrm{LPH} 7\right)$. The Unit 3 LPH7 shows an increase of TR during load increment having slight or no off design condition reaching to almost $25^{\circ} \mathrm{C}$ at high load. The LPH6 on Unit 2 and Unit 3 also increased during load increment but Unit 3 has rather a decreasing TR at early low load but becomes significantly stable during high load.

In summary, the results show that all heaters of the three units significantly increases within design range as the load was increased except for the last stage heater LPH7 on the Unit 1 and 2. The HPH2 TR on Unit 2 has seen to be working very high especially at higher loads. A high TR, as mentioned earlier, could also be a disadvantage that may lead to over stressing of the internal parts at longer operating time. Thus, we must keep in mind that a heater is designed with specifications by manufacturers with an allowable temperature limit.

Extraction steam flow requirement results: The Figure 16 showed the extraction steam flow requirement on the high-pressure heaters
HPH1 and HPH2 at the three units. HPH1 showed that it's the same flow results at the three units from around $1.2 \mathrm{t} / \mathrm{h}$ to $4.4 \mathrm{t} / \mathrm{h}$. The HPH2 per unit somehow has slight different flow requirement based from the test results of $7.5 \mathrm{t} / \mathrm{h}, 9.4 \mathrm{t} / \mathrm{h}$ and $8.2 \mathrm{t} / \mathrm{h}$, respectively. On the Figure 17, the extraction steam flow requirement also shows an increasing trend at load increment from minimum to maximum. The three units' flow value basically were almost near to each other. It increased from at least $2 \mathrm{t} / \mathrm{h}$ to near $7 \mathrm{t} / \mathrm{h}$.

The Figure 18 showed the trend characteristic results for the extraction steam requirement on the low-pressure heaters LPH4 and LPH5. The first low pressure heater LPH4 showed same flow value with the other units averaging around $1.3 \mathrm{t} / \mathrm{h}$ to $4.5 \mathrm{t} / \mathrm{h}$ minimum and maximum. The LPH5 somehow have different flow at the higher load per each unit where Unit 1 required $6.5 \mathrm{t} / \mathrm{h}$, Unit 2 required $6.3 \mathrm{t} / \mathrm{h}$ and Unit 3 required $5.5 \mathrm{t} / \mathrm{h}$ at full load.

Finally, the Figure 19 showed the results on the extraction steam flow requirement at the last two low pressure heater LPH6 and LPH7. It showed that the heater has different flow requirement during the test. The possible cause for these different flows may be because of the offdesign conditions experiencing by the two units, Unit 1 and 2 . 
Citation: Almedilla JR, Pabilona LL, Villanueva EP (2018) Performance Evaluation and Off Design Analysis of the HP and LP Feed Water Heaters on a $3 \times 135$ MW Coal Fired Power Plant. J Appl Mech Eng 7: 308. doi:10.4172/2168-9873.1000308

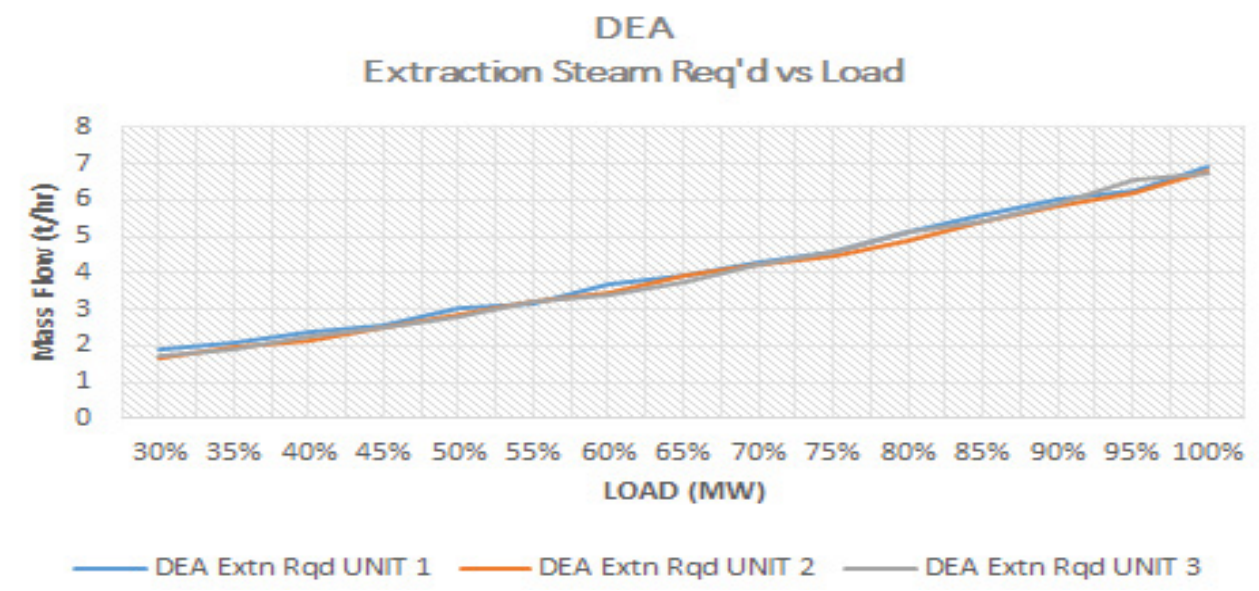

Figure 17: DEA extraction steam flow required.

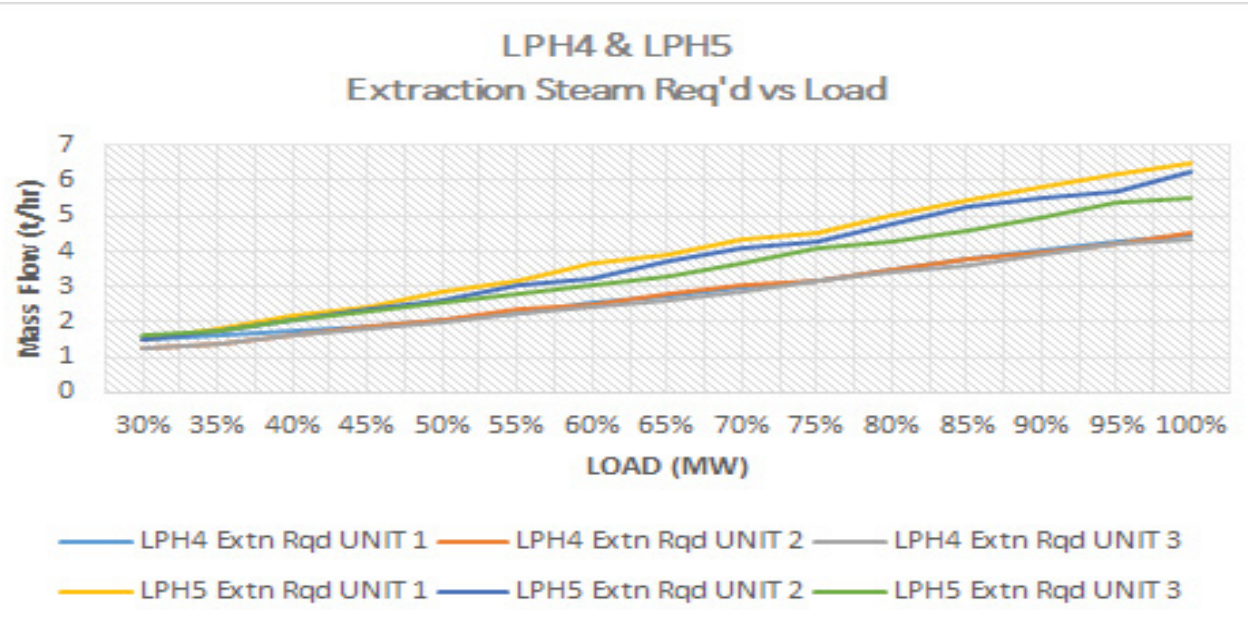

Figure 18: LPH4 and LPH5 extraction steam flow required.

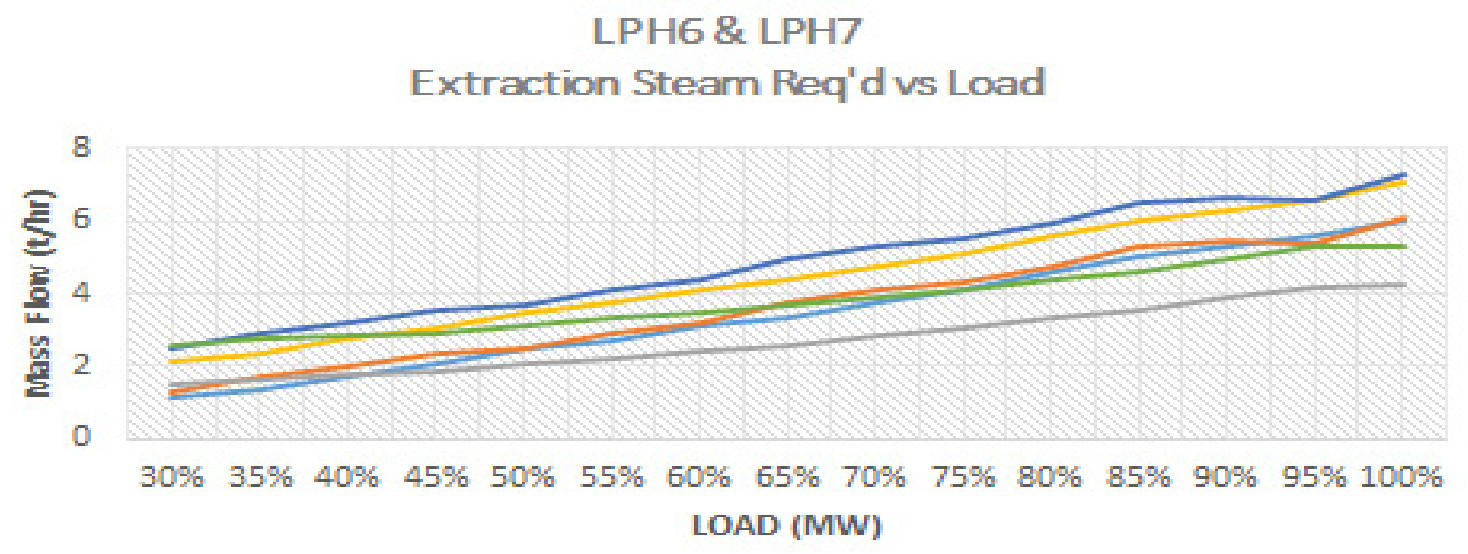

LPH6 Extn Rqd UNIT 1 L LPH6 Extn Rqd UNIT 2 - LPH6 Extn Rqd UNIT 3

LPH7 Extn Rqd UNIT 1 L LPH7 Extn Rqd UNIT 2 LPH7 Extn Rqd UNIT 3

Figure 19: LPH6 and LPH7 extraction steam flow required. 
In summary, the results show that the extraction steam flow requirement increases as the load is increased. This supports the idea that a feed water heater flow is self-regulating as explained by Ashok Kumar, Buckshumiyanm [7] based from his references.

\section{Comparative analysis of the three units}

Gathering information from all of the figures on the previous pages of the results, it shows that all high-pressure heaters (HPH1 and HPH2) performed better at both maximum and load variable. The DEA heater also showed the same performance of TR on all the units averaging near the design value $38.6^{\circ} \mathrm{C}$. Low pressure heaters such as LPH4, LPH5 and LPH6 were also remarkable and can be considerably performing fair within its designed levels where TTD decreased at load increment. However, on the last stage heater LPH7 reveals different for Unit 1 and Unit 2 where it encounters most off design at any load. The Unit 3 LPH7 although with slight off design due to high TTD, it shows that its TR was working normally. An increase in TTD and DCA while a decrease in TR could be a deterioration of performance with possible causes according to Bode and Gore [9]:

1. Fouled heater tubes (either steam or water side).

2. Internal Leakage (leakage through the water box partition plate resulting in a partial internal bypassing of the heater, or, tube-totube sheet leakage resulting in feed water leaking to the steam side).

3. External leakage (through the bypass valve).

4. Plugged tubes (reducing the heat transfer area, while increasing tube velocity).

There were also observed frequent opening of LPH6 emergency drain valves due to high water level on Unit 1 and Unit 2 as noted during the test. Frequent opening of LPH6 emergency drain to condenser can also be a problem since it damp heat energy to condenser without utilizing at the LPH7. The problem also explains at the previous study by Kumar [7]. This can be improved when an inspection or repair during maintenance period of the heaters if found any problem on the heaters internal parts. Proper actions must be taken to prevent equipment deterioration or degradation. As observe from the test, the Units 1 and 2 LPH6 emergency drain valves frequently opens to drain water to the condenser which may cause improper transfer of heat from LPH7.

\section{Heaters mathematical model equation-based form the result} of the five tests

Each unit's feed water heaters performance indicators (TTD, DCA and TR) test and extraction steam flow requirement results were plotted and make a regression using MatLab Software R2013a. These equations can be a useful tool for a performance engineer to further evaluate the results and can be used by operators for each unit's optimized performance. The regression equations of each heaters are as followed using cubic equation model;

Unit 1

HPH1:

$$
\begin{aligned}
& \text { TTD: } y=(-7.5 e-07) x^{3}+0.00047 x^{2}-0.023 x+2.6 \\
& \text { DCA: } y=(4.4 e-07) x^{3}+(-8.3 e-05) x^{2}+0.007 x-0.93 \\
& \text { TR: } y=(4.1 e-06) x^{3}-0.0014 x^{2}+0.17 x+13 \\
& \text { Extn: } y=(2.2 e-07) x^{3}+(2.3 e-05) x^{2}+0.022 x+0.18
\end{aligned}
$$

\section{HPH2:}

TTD: $\mathrm{y}=(-6.1 \mathrm{e}-07) \mathrm{x}^{3}+0.0004 \mathrm{x}^{2}-0.018 \mathrm{x}+0.072$

DCA: $y=(1 e-06) x^{3}-0.00014 x^{2}+0.0092 x+0.99$

TR: $y=(6.2 e-06) x^{3}-0.0019 x^{2}+0.23 x+26$

Extn: $y=(1.9 e-07) x^{3}+0.00011 x^{2}+0.033 x+0.59$

DEA:

TR: $\mathrm{y}=(-2.4 \mathrm{e}-06) \mathrm{x}^{3}+0.0005 \mathrm{x}^{2}+0.054 \mathrm{x}+28$

Extn: $\mathrm{y}=(-1.7 \mathrm{e}-07) \mathrm{x}^{3}+0.00024 \mathrm{x}^{2}+0.016 \mathrm{x}+0.83$

LPH4:

TTD: $\mathrm{y}=(-3.1 \mathrm{e} 06) \mathrm{x}^{3}+0.0013 \mathrm{x}^{2}-0.17 \mathrm{x}+13$

DCA: $\mathrm{y}=(2.4 \mathrm{e}-05) \mathrm{x}^{3}-0.0089 \mathrm{x}^{2}+1.1 \mathrm{x}-20$

TR: $y=(-2 e-05) x^{3}+0.006 x^{2}-0.55 x+42$

Extn: $y=(-1.6 e-06) x^{3}+0.00055 x^{2}-0.024 x+1.7$

LPH5:

TTD: $y=(-2.7 e-05) x^{3}+0.009 x^{2}-x+48$
DCA: $y=(2.4 e-05) x^{3}-0.0089 x^{2}+1.1 x-20$
TR: $y=(1.6 e-05) x^{3}-0.0056 x^{2}+0.73 x+4.9$
Extn: $y=(-1 e-06) x^{3}+0.0003 x^{2}+0.025 x+0.055$

LPH6:

TTD: $\mathrm{y}=(-2.4 \mathrm{e}-05) \mathrm{x}^{3}+0.0077 \mathrm{x}^{2}-0.85 \mathrm{x}+56$

DCA: $y=(2.5 e-05) x^{3}-0.0077 x^{2}+0.87-8.6$

TR: $y=(2.5 e-05) x^{3}-0.0069 x^{2}+0.85 x-5.7$

Extn: $\mathrm{y}=(-2.8 \mathrm{e}-07) \mathrm{x}^{3}+0.00013 \mathrm{x}^{2}+0.037 \mathrm{x}-0.57$

LPH7:

TTD: $\mathrm{y}=(4.8 \mathrm{e}-06) \mathrm{x}^{3}-0.0015 \mathrm{x}^{2}+0.18 \mathrm{x}+41$

DCA: $\mathrm{y}=(-9.7 \mathrm{e}-06) \mathrm{x}^{3}+0.0016 \mathrm{x}^{2}+0.094 \mathrm{x}-1.5$

TR: $\mathrm{y}=(3.4 \mathrm{e}-06) \mathrm{x}^{3}-0.0013 \mathrm{x}^{2}+0.15 \mathrm{x}-2.3$

Extn: $\mathrm{y}=(-2.8 \mathrm{e}-07) \mathrm{x}^{3}+0.00013 \mathrm{x}^{2}+0.037 \mathrm{x}+0.43$

Unit 2

HPH1:

TTD: $\mathrm{y}=(-2.9 \mathrm{e}-06) \mathrm{x}^{3}+0.0011 \mathrm{x}^{2}-0.083 \mathrm{x}+2.6$

DCA: $y=(1.2 \mathrm{e}-07) \mathrm{x}^{3}-(5.1 \mathrm{e}-05) \mathrm{x}^{2}+0.0086 \mathrm{x}-2.8$

TR: $=(-1.8 \mathrm{e}-06) \mathrm{x}^{3}+0.00026 \mathrm{x}^{2}+0.034 \mathrm{x}+17$

Extn: $y=(-4.3 e-08) x^{3}+0.0001 x^{2}+0.018 x+0.22$

HPH2:

TTD: $\mathrm{y}=(-4.2 \mathrm{e}-06) \mathrm{x}^{3}+0.0014 \mathrm{x}^{2}-0.11 \mathrm{x}+2.2$

DCA: $\mathrm{y}=(-5.3 \mathrm{e}-06) \mathrm{x}^{3}+0.0017 \mathrm{x}^{2}-0.13 \mathrm{x}+15$

$T R: y=(-5.8 e-05) x^{3}+0.016 x^{2}-1.4 x+82$

Extn: $y=(-2.4 e-06) x^{3}+0.00092 x^{2}-0.03 x+2.6$

DEA: 
TR:y $=(1.2 \mathrm{e}-05) \mathrm{x}^{3}-0.0038 \mathrm{x}^{2}+0.45 \mathrm{x}+16$

Extn: $y=(1.2 e-06) x^{3}-0.00015 x^{2}+0.051 x-0.27$

LPH4:

TTD: $\mathrm{y}=(-6.3 \mathrm{e}-06) \mathrm{x}^{3}+0.0022 \mathrm{x}^{2}-0.26 \mathrm{x}+15$

DCA: $\mathrm{y}=(6.6 \mathrm{e}-06) \mathrm{x}^{3}-0.0019 \mathrm{x}^{2}+0.17 \mathrm{x}+8.8$

TR: $y=(-3.2 e-07) x^{3}-0.011 x^{2}+0.078 x+20$

Extn: $y=(-3.5 e-07) x^{3}+0.00014 x^{2}+0.02 x+0.21$

LPH5:

TTD: $\mathrm{y}=(-8.7 \mathrm{e}-06) \mathrm{x} 3+0.0032 \mathrm{x} 2-0.4 \mathrm{x}+27$

DCA: $y=(7.3 e-06) \times 3-0.0025 x 2+0.32 x+9.8$

TR:y $=(-5 e-06) x 3+0.00079 x 2+0.09 x+23$

Extn: $y=(-1.5 e-06) x 3+0.00047 x 2+0.0053 x+0.63$

LPH6:

TTD: $y=(-1.6 e-05) x^{3}+0.0053 x^{2}-0.63 x+52$

DCA: $\mathrm{y}=(2.3 \mathrm{e}-05) \mathrm{x}^{3}-0.0072 \mathrm{x}^{2}+0.8 \mathrm{x}-4.7$

TR: $y=(-7.6 e-07) x^{3}-0.0012 x^{2}+0.34 x+12$

Extn: $y=(-2.6 e-06) x^{3}+0.00068 x^{2}-0.0042 x+0.58$

LPH7:

TTD: $\mathrm{y}=(-4.5 \mathrm{e}-05) \mathrm{x}^{3}+0.012 \mathrm{x}^{2}-1 \mathrm{x}+62$

DCA: $y=(4.6 e-06) x^{3}-0.0017 x^{2}+0.29 x-4$

TR: $\mathrm{y}=(3.2 \mathrm{e}-05) \mathrm{x}^{3}-0.0074 \mathrm{x}^{2}+0.54 \mathrm{x}-8.1$

Extn: $y=(-2.6 e-06) x^{3}+0.00068 x^{2}-0.045 x+1.8$

Unit 3

HPH1:

TTD: $\mathrm{y}=(-5.7 \mathrm{e}-06) \mathrm{x}^{3}+0.0019 \mathrm{x}^{2}-0.15 \mathrm{x}+4.9$

DCA: $y=(-3.5 e-07) x^{3}+0.00021 x^{2}-0.038 x-0.18$

TR:y $=(1.5 \mathrm{e}-06) \mathrm{x}^{3}-0.00088 \mathrm{x} 2+0.15 \mathrm{x}+14$

Extn: $y=(-8.6 e-07) x^{3}+0.00031 x^{2}+0.0028 x+0.6$

\section{HPH2:}

TTD: $\mathrm{y}=(-9.8 \mathrm{e}-07) \mathrm{x}^{3}+0.00034 \mathrm{x}^{2}+0.0068 \mathrm{x}-0.81$

DCA: $y=(4.4-08) x^{3}-0.00015 x^{2}+0.041 x+6.7$

TR: $\mathrm{y}=(-3.2 \mathrm{e}-06) \mathrm{x}^{3}+0.00042 \mathrm{x}^{2}+0.07 \mathrm{x}+32$

Extn: $y=(-2.5 e-06) x^{3}+0.00079 x^{2}-0.014 x+1.7$

DEA:

TR: $\mathrm{y}=(3.8 \mathrm{e}-06) \mathrm{x}^{3}-0.0011 \mathrm{x}^{2}+0.19 \mathrm{x}+23$

Extn: $y=(-5.6 e-07) x^{3}+0.00036 x^{2}+0.0058 x+0.95$

LPH4:

TTD: $\mathrm{y}=(-6.3 \mathrm{e}-06) \mathrm{x}^{3}+0.0022 \mathrm{x}^{2}-0.25 \mathrm{x}+15$

DCA: $y=(4.7 e-06) x^{3}-0.0012 x^{2}+0.073 x+11$

TR: $y=(1.3 e-06) \mathrm{x}^{3}+0.00022 \mathrm{x}^{2}+0.041 \mathrm{x}+21$
Extn: $y=(-6.5 e-7) x^{3}+0.00025 x^{2}+0.0059 x+0.65$

\section{LPH5:}

TTD: $\mathrm{y}=(-1.1 \mathrm{e}-05) \mathrm{x}^{3}+0.0038 \mathrm{x}^{2}-0.45 \mathrm{x}+28$

DCA: $y=(-2.5 e-06) x^{3}+0.00091 x^{2}-0.086 x+24$

TR:y $=(-4.4 \mathrm{e}-06) \mathrm{x}^{3}+0.0011 \mathrm{x}^{2}-0.032 \mathrm{x}+28$

Extn: $y=(-1 e-06) x^{3}+0.00038 x^{2}+0.0019 x+0.99$

LPH6:

TTD: $\mathrm{y}=(-2.5 \mathrm{e}-05) \mathrm{x}^{3}+0.0082 \mathrm{x}^{2}-1.1 \mathrm{x}+71$

DCA: $y=(-2.2 e-06) x^{3}+0.0015 x^{2}-0.21 x+27$

TR: $y=(1.2 \mathrm{e}-05) \mathrm{x}^{3}-0.0043 \mathrm{x}^{2}-0.46 \mathrm{x}+38$

Extn: $y=(-7.8 e-07) x^{3}+0.00035 x^{2}-0.12 x+1.5$

LPH7:

TTD: $\mathrm{y}=(-3.4 \mathrm{e}-05) \mathrm{x}^{3}+0.12 \mathrm{x}^{2}-1.5 \mathrm{x}+(1 \mathrm{e}+02)$

DCA: $\mathrm{y}=(4.6 \mathrm{e}-06) \mathrm{x}^{3}-0.0024 \mathrm{x}^{2}+0.45 \mathrm{x}-8.2$

TR: $y=(2 \mathrm{e}-05) \mathrm{x}^{3}-0.0079 \mathrm{x}^{2}+1.1 \mathrm{x}-31$

Extn: $\mathrm{y}=(-7.7 \mathrm{e}-07) \mathrm{x}^{3}+0.00035 \mathrm{x}^{2}-0.011 \mathrm{x}+2.6$

Where, $\mathrm{y}=$ Performance Indicator $\left({ }^{\circ} \mathrm{C}\right.$ or $\left.\mathrm{t} / \mathrm{h}\right)$

$\mathrm{x}=\operatorname{load}(\mathrm{MW})$

\section{Conclusions}

1. Based from the results above, all units High Pressure Feed Water Heaters were performing better with low TTD and DCA and high TR. The last stage feed water heaters of Units 1 and 2 seem to be performing badly due to high TTD and DCA with low TR even at maximum load.

2. During load adjustment between minimum to maximum, the performance trend characteristics and extraction steam flow requirement trend of each heater are similar with the three units except for the last 2 stage heaters (LPH6 and LPH7). The two last stage heaters of Unit 3 perform better during load adjustments while the other two units last stage heaters are almost offline due to very low increase in feed water temperature and off design conditions. The last stage heaters of Units 1 and 2 shows an offdesign conditions all throughout its load adjustments which could be a serious problem on its efficiency.

3. Comparing all three units, the Unit 3 shows a better performance on its feed water heaters due to the last stage heater results.

4. Finally, a mathematical model equation of non-linear regression was shown for each heaters performance during the five tests at load adjustments of $5 \%$ between minimum and maximum load. These equations can be used for simulations of the feed water heater systems of each units' performance and extraction steam flow ideal requirement. The mathematical model for Unit 1 and 2 last 2 stage extraction heaters may not yet be final unless proper solutions and actions are made to prevent off its off-design conditions.

\section{Recommendations} paper;

The following can be recommended for further studies of this 
Citation: Almedilla JR, Pabilona LL, Villanueva EP (2018) Performance Evaluation and Off Design Analysis of the HP and LP Feed Water Heaters on a $3 \times 135$ MW Coal Fired Power Plant. J Appl Mech Eng 7: 308. doi:10.4172/2168-9873.1000308

Page 14 of 14

1. Inspection or repair, if any problems found during maintenance check-up for the last stage heater (LPH7).

2. More routine performance test before and after annual planned outage to monitor equipment degradation or improvement.

3. Include calculation of the feed water heaters efficiency and relate it to the overall cycle efficiency or heat rate performance.

\section{Acknowledgement}

The authors wish to thank the University of Science and Technology of Southern Philippines (USTP) faculty and colleagues for their patience and support on the paper. Their guidance and knowledge were a helpful tool in the author's motivation. A special thank you to the main author's immediate supervisors for participating and helping gather the necessary data needed on the paper.

\section{References}

1. Kiameh $P$ (2002) Ower generation handbook: Selection, applications, operation and maintenance. McGraw-Hill Handbook pp: 1-560.

2. Nag PK (1981) Power plant engineering. The McGraw-Hill companies $3^{\text {rd }}$ edition, New Delhi 2:1.

3. Cengel YA, Boles MA (2008) Mechanical engineering: Thermodynamics. McGraw-Hill Book pp: 1-930.
4. Black \& Veatch (1996) Power plant engineering. Springer berlin heidelberg New York, USA.

5. Kumar CV, Kumar D (2014) Performance analysis of regenerative feed heating in a steam plant. IOSR-JMCE 11: 1-8.

6. Kushawaha KC, Koshti B (2015) Performance analysis and off design behaviour of feed water heater. IJAME 3: 9-15.

7. Kumar A (2017) Performance analysis of regenerative feed water heaters in $210 \mathrm{MW}$ thermal power plant. IRJET 8: 1490-1495.

8. Buckshumiyanm A, Sabarish R (2017) Performance Analysis of regenerative feedwater heaters in $210 \mathrm{MW}$ thermal power plant. IJPAM 116: 25-29.

9. Bode VV, Gore VG (2016) Performance analysis of regenerative feed water Heating system in $270 \mathrm{MW}$ thermal power plant. IRJET 3: 1180-1186.

10. Devandiran E, Shaisundaram VS, Ganesh PB, Vivek S (2016) Influence of feed water heaters on the performance of coal fired power plants. IJLTEMAS 5: 115-119.

11. Klink (1989) An improved method for trending feed water heater performance. El International Inc 2: 1.

12. The American Society of Mechanical Engineers (1978) Performance test code 12.1. closed feed water heaters.

13. Heat Exchange Institute (HEI) Incorporated standards for closed feed water heaters $8^{\text {th }}$ edition $\mathrm{pp}: 1-71$.

14. Alto $P$ (2015). Thermal performance engineering handbook, volume 3 EPR pp: 1-201. 